Cockatoos, and Parrakeets, which had abundant room to fly about. Dr. Chalmers Mitchell stated that although the majority of these birds had been in the Aviary throughout the winter, with no artificial heat and with no other shelter than a number of nesting-boxes, the rate of mortality had been very low, lower indeed than that in the artificially-heated Parrot House, and that thie general health of the birds had been extremely good. $\mathrm{He}$ pointed out that people were too much inclined to suppose that because creatures were now found in the Tropics a tropical climate was necessary to their existence or comfort, and suggested that Geologists should not be too rash in ascribing a warmer climate in past times to any particular region because of the presence of fossil remains of creatures now tropical in their habitat.

After a vote of thanks had been given to Dr. Chalmers Mitchell on the motion of Dr. Smith Woodward, the President of the Association, the party dispersed, many of its members visiting the Gardens in more detail.

\title{
EXCURSION TO SHOOTER'S HILL, BLACKHEATH, AND LEWISHAM.
}

Saturday, March $25 \mathrm{Th}, 1905$.
Directors: A. E. Salter, D.Sc., F.G.S., and A. C. Young, F.C.S.

(Report by The DiReCtors.)

ON arriving at Well Hall Station the party, numbering 35, proceeded to Shooter's Hill, and, on reaching the stile at Castlewood, the main features of the landscape were pointed out, and the presence of London Clay noted in some small exposures. Reference was also made to the many items of historical interest connected with Shooter's Hill, and the mention of it by Lord Byron in one of his works

By the kindness of Probyn Godson, Esq., the grounds of Castlewood House were entered, and a small gravel pit, by the side of the path leading to the Bull Inn, was investigated. This is several feet below the summit of the hill, and the gravel has probably been derived from the higher deposits at the top. It was pointed out that it was to the presence of this capping of gravel that Shooter's Hill had been preserved, whereas the London Clay strata all round had been denuded away.

The party then proceeded to Severndroog Castle, which was erected in the eighteenth century as a memorial of the capture of the Severndroog pirates on the Malabar Coast of India, by Sir William James in $\mathbf{r} 755$. 
The views from the top are exceedingly fine. On a clear day Windsor Castle can be seen, and by the aid of glasses the Chiltern Hills, above Nettlebed, beyond.

The gravel pits beyond the Bull Inn, and to the east of Shrewsbury Lane, were next visited. These are situated close to the highest point, and are about $424 \mathrm{ft}$. O.D. Mr. F. C. G. Spurrell described the gravel in i 886 ( $c f$. references).

It was found to consist almost entirely of Tertiary flint pebbles. Among other rocks more rarely found may be mentioned subangular flints, quartz pebbles, jasper, ironstone, and dark chert, with secondary quartz veining, all of which might be derived from the south. Lower Greensand Chert from the Hythe Beds of the Wealden area does not appear to occur.

Mr. B. Polkinghorne, B.Sc., exhibited on behalf of himself and Mr. A. P. Leach a series of Neolithic implements obtained on the surface of the hill, also a Modiola Sp. (? Flegans), Corbula Sp., and a piece of selenite from the London Clay below the gravel.

Reference was made to the Mineral Well on the N.W. side behind the Eagle. Time, however, did not allow the party to visit it. It is mentioned by Evelyn in his diary, 1699.

Proceeding towards Blackheath a small section in the Blackheath Beds, close to Morden College (built in I695), was examined. Between this section and the College is a small valley which is now dry. This is the upper part of the same valley in which the sections at Belmont Hill, Lewisham, are situated.

Passing along the south side of Blackheath and down Love Lane to Belmont Hill, by the kindness of Messrs. $H$. and $G$. Taylor, the party investigated an interesting series of sections showing Thanet Sand, and Woolwich and Reading Beds in which the Shell Beds had been well exposed. The latter beds were covered by an interesting recent gravel and clay deposit, which showed good evidence of hill creep, but owing to the heavy rain of the previous week they were not in good condition.

There was about $17 \mathrm{ft}$. of Thanet Sand exposed, above which was $4 \mathrm{ft}$. of green sandy clay containing pebbles, showing the irregular junction with the Thanet Sand; above this $3 \mathrm{ft}$. of yellowish sandy pebbles, then $3 \mathrm{ft}$. of hard red clay with pebbles apparently representing the mottled clay of other sections; then followed $3 \mathrm{ft}$. of a yellowish sandy pebble-bed, and $2 \mathrm{ft}$. of cyrena shell-bed with a thin oyster-bed at the top. Above this was, in the upper of the two sections, ro ft. of gravel, which in some places cut into and was thrust under the shell-bed. At the base of the shell-bed some very hard flinty " race" was found, which on analysis by Mr. H. Dixon Hewitt, gave the following composition: 


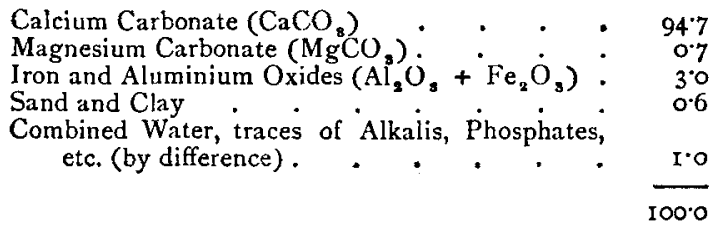

A sample of the red clay was also analysed by Mr. Hewitt, with the following result :

Ferric Oxide $\left(\mathrm{Fe}_{2} \mathrm{O}_{3}\right)$. . . . . . $7 . \mathrm{I}^{*}$

Hygroscopic Moisture . . . . . . . $\quad 9^{*}$

Loss on Ignition (not including hygroscopic moisture) . . . . . . . 47

\section{Generalized Section of the Two Pits on South Side of Belmont Hill Estate.}

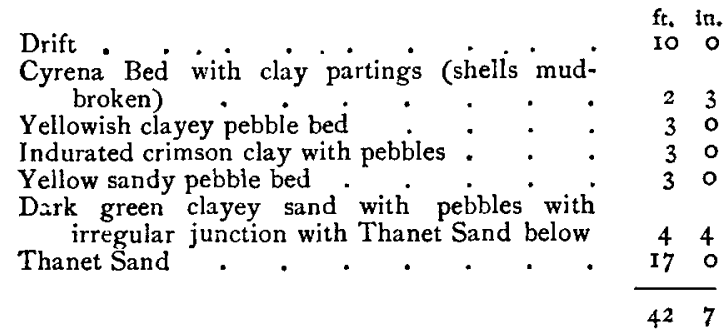

In the lowest part of the estate, beneath the site of an old pond, a deep excavation had been made, and a fine example of Drift exposed some $15 \mathrm{ft}$. thick. Much discussion ensued on its precise mode of origin, but it was felt that to decide this the relation of the Thanet Sand. below to the Chalk needed to be made out. It was composed largely of Tertiary pebbles and sand with some subangular flints, and appeared to have been deposited tumultuously.

Drift Section in River Valley at the foot of the Hill JUst South of the South-Eastern RaIlway.

$\left\{\begin{array}{l}\text { Contorted gravel and sand with occasional clayey } \\ \text { patches } \\ \text { Unevenly bedded Drift, principally made up of } \\ \text { Woolwich and Blackheath pebbles, with sub- } \\ \text { angular flints } \\ \text { Thanet Sand }\end{array}\right.$

* Iron (Fe) 5 'O. ft. in.

60

90

$\frac{150}{300}$ 
IO6 EXCURSION TO SHOOTER'S HILL, BLACKHEATH, AND LEWISHAM.

If there has been no sinking of the Thanet Sand from solution of the underlying Chalk, the total thickness of Thanet Sands exposed in the three sections would be $42 \mathrm{ft}$, and as the greatest thickness in that district has been given as $50 \mathrm{ft}$., the Chalk should be reached within Io ft. Messrs. Taylor have kindly promised to put a boring down to prove this.

The Upper Beds of Drift seem to have been laid down tumultuously, many of the pebbles being on end. A large green quartzite pebble from the Blackheath Beds was found, but. no other "foreign" rocks were observed and no trace of the overlying shell beds.

The lower part of the Drift is unevenly bedded, but shows signs of stratification. Near the base occur streaks of black sand, an analysis of which, by Mr. H. Dixon Hewitt, gave the following result :

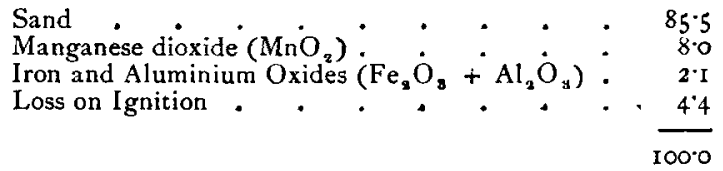

This river-valley seems to have been the principal drainage system from the high ground round Blackheath and Shooter's Hill towards the Ravensbourne at Lewisham, but the head of the valley was subsequently cut off by the present river Quaggy, which flows by Kidbrook and Lee to Lewisham.

The members of the Catford Natural History Society had paid much attention to these sections, and the Secretary, Mr. W. H. Griffin, exhibited some fine full-plate photos taken when the sections were at their best. Mr. Hewitt, the Registrar, had also made the above chemical analyses :

Those members who did not proceed at once to London took tea at Till's Restaurant near the Obelisk, Lewisham, where a hearty vote of thanks was accorded the Directors, who suitably responded.

\section{REFERENCES.}

1889. W. Whitaker.- "Geology of London." Mem. Geol. Survey, vol, i, pp. 244, 295, 482, etc.

1886. F. C. G. SPURRELL. "A Sketch of the Rivers and Denudation of West Kent," pp, 4 and 5 (privately printed).

- W. T. VINCENT.- "Records of the Woolwich District."

I89r. "Records of Excursions," pp. 4-8.

I905. A. E. SAITER.- "On the Superficial Deposits of Central and Parts of Southern England." Proc. Geol. Assoc, vol. xix, p. 8.

See also Quarterly Fournal of the Geological Society, vol. ix, p. 290 and Plate XIII ; vol. xxxviii, Plate XXVI ; vol. xliv, Plate V.

Since the above excursion there has been a new road cut from Well Hall Station to Eltham Church, giving a very interesting 
section in Blackheath Beds, which rise from under the London Clay which has been exposed close to the railway bridge. There is exposed about $5 \mathrm{ft}$. of shell-bed, the upper part very much decalcified in parts, giving the shell-bed the appearance of a series of crags surrounded by the pebble bed. The oyster bed has been much indurated along one or two horizons, and some very good specimens can be obtained. The following fossils have been found by our members: Odontaspis elegans (abundant), Phyllodus (two species), Otodus obliquus, Carcharadon, Vertebræ of Shark, Ostrea bellovacina, O. tenera, Modiola, Cerithum, etc.

Being only a temporary section an early visit is advisable.

\title{
EXCURSION TO GERRARD'S CROSS, BUCKS.
}

\author{
Saturday, APRIL IST, I905. \\ Director: R. C. Sikes, B.A., M.Inst.C.E. \\ Excursion Secretary: A. H. Williams. \\ (Report by THE DIRECTOR.)
}

ON reaching Uxbridge Station the party of twenty-two members and friends walked in a northerly direction along the bank of the Grand Junction Canal, to the point at which it is crossed by the new G.W.R. and G.C.R line, and then followed the railway westwards to Gerrard's Cross. The first cutting passed through was that at Doggett's Farm, where the section is similar to that afterwards examined at Gerrard's Cross, but is not so well exposed. The long cutting at Gerrard's Cross, through the high ground to the west of the River Misbourne, showed the following general section from the east end to the centre of the cutting :
I. Plateau Gravel (sand and gravel)
from 16 to 25
2. London Clay (dark grey and brown sandy clay) abcut
3. Reading Beds (blue and mottled clay) . . .
15

The section at the west end of the cutting was as follows :

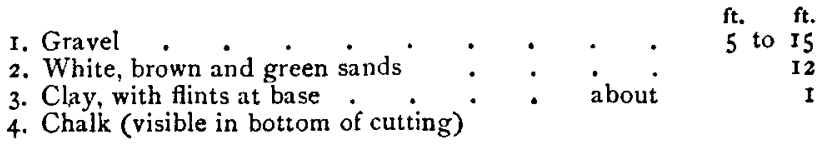

A few teeth were found by the party in the London Clay band, and some characteristic London Clay shells, mostly in a bad state of preservation.

Attention was drawn to the fact of the London Clay band 